\title{
Twenty years monitoring growth dynamics of a logged tropical forest in Western Amazon
}

\author{
Marcus Vinicio Neves d'Oliveira1*, Luis Claudio Oliveira1', Mário Humberto Aravena Acuña², Evaldo Muñoz Braz³ \\ ${ }^{1}$ Embrapa Acre, Rodovia BR-364, Km 14 (Rio Branco/Porto Velho), CP. 321, CEP 69900-970, Rio Branco, AC, Brazil \\ ${ }^{2}$ Universidade Federal do Acre, BR 364, Km 4, Distrito Industrial,CEP 69920-900, Rio Branco, AC, Brazil \\ ${ }^{3}$ Embrapa Florestas, Estrada da Ribeira, Km 111, CP. 319, CEP 83411-000, Colombo, PR, Brazil
}

"Corresponding author:

marcus.oliveira@embrapa.br

Index terms:

Forest management

Above-ground biomass

Experimental plots

Termos para indexação:

Gestão florestal

Biomassa acima do solo

Parcelas experimentais

Received in 17/01/2017

Accepted in 07/12/2017

Published in 29/12/2017

doi: 10.4336/2017.pfb.37.92.1398

\begin{abstract}
We performed a forest growth dynamics study in Acre State, Brazilian southwestern Amazon, where a 20 ha area was logged in 1992. The study was based permanent sample plots ( 1 ha) established in the logged area and in an unlogged forest immediately after logging operations finished. Forest dynamics parameters were assessed in terms of aboveground dried biomass (AGB). During the study period, three extreme climate events triggered a high impact on both logged and unlogged areas, producing AGB losses greater than those estimated for logging. Twenty years after logging, ingrowth and mortality rates were similar to those expected in an undisturbed forest, and AGB recovery was significantly faster in the logged areas. Forest management, when properly applied, can promote faster forest AGB recovery. We suggest that forest management could be considered as an alternative to adapt to extreme climate events, by promoting controlled disturbances, which should minimize tree mortality and biomass loss.
\end{abstract}

\section{Vinte anos monitorando a dinâmica de crescimento de uma floresta tropical explorada na Amazônia ocidental}

Resumo - Foi conduzido um estudo sobre a dinâmica de crescimento em floresta localizada no Estado do Acre na Amazônia sul ocidental, onde uma área de 20 ha foi explorada para extração de madeira em 1992. O estudo foi baseado em parcelas permanentes ( $1 \mathrm{ha}$ ) estabelecidas dentro da área explorada e na floresta não manejada, imediatamente após o fim das operações florestais. Os parâmetros da dinâmica florestal foram analisados em termos da biomassa seca acima do solo (BAS). Durante o período do estudo três eventos climáticos extremos causaram um elevado impacto tanto nas áreas exploradas como nas não perturbadas por exploração, produzindo perdas de biomassa superiores às estimadas para a exploração. Vinte anos após a exploração, as taxas de ingresso e mortalidade foram semelhantes às esperadas em uma área de floresta não perturbada por exploração e a recuperação da BAS foi significativamente mais alta nas áreas cortadas. Quando praticado de forma adequada, o manejo de floresta pode promover uma recuperação da BAS mais rápida. Nós sugerimos que o manejo florestal pode ser considerado como uma alternativa para adaptação a eventos extremos de clima por meio da promoção de perturbações controladas que minimizem a mortalidade de árvores e a perda de biomassa.

\section{Introduction}

Tropical forest conservancy is a priority because these forests play an important role in climate regulation as sinks for greenhouse gases (GHG) and in carbon stock maintenance (Pan et al., 2011). Although there is no consensus on the sustainability of tropical forest management for timber production (Zimmerman \& 
Kornos, 2012), this practice is common in tropical forests of Africa, Asia and Latin America. The effects of logging operations on forest structure and dynamics vary according to logging intensity and applied forest management regime (Blanc et al., 2009; West et al., 2014). The available results indicate that the residual effects of logging tend to be diluted over the cutting cycle length, and fast aboveground biomass recovery is usually observed (Oliveira et al., 2013; Gourlet-Fleury et al., 2013).

In general, the compliance with the reduced-impact logging (RIL) guidelines on planning and performing logging operations (Nebel et al., 2001; Macpherson et al., 2010; Miller et al., 2011) decreases the likelihood of forest degradation (Putz \& Redford, 2010) and leads to the maintenance of biodiversity (Bicknell et al., 2015), carbon stocks and environmental services. Performed according to the RIL prescriptions, forest management can be considered as the best land use alternative for tropical forest conservation (Edwards et al., 2014).

Worldwide, long-term studies of managed forest growth dynamics are largely recognized as the best way to predict production, determine logging cycles and intensities, recommend silvicultural treatments and verify the sustainability of timber production in tropical forests (Fredericksen \& Mostacedo, 2000; Fredericksen \& Putz, 2003; Dauber et al., 2005; Wadsworth \& Zweede, 2006; Sist \& Ferreira, 2007; Villegas et al., 2008). Tropical forest growth dynamics have been studied for decades (Sheil, 1998; Malhi et al., 2002; Lewis et al., 2004; Laurance et al., 2009), but despite the scientists' efforts and the formation of international networks such as Rainfor (Malhi et al., 2002) and more recently the Tropical Managed Forest Observatory (TMFO) (Sist et al., 2015) dedicated to organizing, sharing results and promoting forest dynamics studies, long-term studies are still scarce and insufficient to represent the behavior of tropical forest ecosystems and applied forest management methods.

Besides logging operations, climate must also be considered as a main effect influencing tropical forest dynamics. The expected increase in the frequency of extreme climate events can produce drastic variations in net primary production (Nemani, et al., 2003; Baker et al., 2004; Boisvenue \& Running, 2006; Toledo et al., 2011) and tree mortality (Nepstad et al., 2004). However, unlike logging impacts, extreme climate events cannot yet be properly predicted and their effects over long logging cycles (e.g. from 20 to 40 years) can either improve or compromise forest production.

The unpredictability of extreme climate events makes it difficult to implement experiments to study their effects on forest growth dynamics. Experiments to observe their effects on tropical forest dynamics have been carried out in small forest areas where climate parameters such as water stress can be artificially controlled (e.g. Nepstad et al., 2007). It is also possible to do this by observing the correspondence between changes in tree mortality or biomass loss (e.g. in permanent sample plots) associated with reported regional or global increase in water stress and temperature (Allen et al., 2010). Thus, there are very few studies where logged forest dynamics and abnormally long drought periods are assessed.

Our objective was to evaluate the changes produced by logging and weather extreme events on the aboveground biomass stocks and forest dynamics parameters (growth, ingrowth and mortality) of a 20 ha tropical forest in the Brazilian Western Amazon, from the logging year (1992) until twenty years after logging.

\section{Methodology}

Embrapa Acre experimental forest is located in Rio Branco, Acre State (9'58'29's; 6744'28' W). The forest management area (20 ha) is covered by a dense highland (terra-firme) tropical forest and was logged in 1992. The forest has a typical well-drained soil, an average volume of around $180 \mathrm{~m}^{3} \mathrm{ha}^{-1}$ of trees over $10 \mathrm{~cm}$ at $1.30 \mathrm{~m}$ above grund level (DBH) and a basal area ranging from $25 \mathrm{~m}^{2} \mathrm{ha}^{-1}$ to $30 \mathrm{~m}^{2} \mathrm{ha}^{-1}$ (Oliveira \& Braz, 1998). The climate is classified as Awi (Köppen) with an annual precipitation of $1,890 \mathrm{~mm}$, and an average temperature of $25^{\circ} \mathrm{C}$. The dry season occurs between June and September and the rainy season lasts from October to April (Boletim..., 1990, 1995). Over the study period, three extreme climate events were reported in the Amazon (Brown et al., 2011; Phillips et al., 2009) and in different countries in 1997-1998, 2005 and 2010, and these produced significant effects on the tropical forest dynamics in Africa, Asia and South America (Allen et al., 2010).

The area was logged following the reduced impact logging techniques. Logging intensity was around $20 \mathrm{~m}^{3} \mathrm{ha}^{-1}$ in a prescribed cutting cycle length of 20 years. Seventeen species were logged and the total volume extracted in the logged permanent sample plots 
was $47.9 \mathrm{~m}^{3}$ or the equivalent to $23.9 \mathrm{~m}^{3} \mathrm{ha}^{-1}$ (Oliveira \& Braz, 1998).

The rainfall data used was from the Rio Branco climate station located about $15 \mathrm{~km}$ from the study area $(-9.96 \mathrm{~S} ;-67.8 \mathrm{~W})$, obtained in the National Institute of Meteorology (INMET) (2014).

The study was based on four 1 ha permanent sample plots (PSP), two established in the logged area and two in an adjacent unlogged forest immediately after logging operations finished. The PSP were square plots of 1 ha, sub-divided into 100 sub-plots of $100 \mathrm{~m}^{2}$ each $(10 \times 10$ $\mathrm{m})$. In these plots, all trees with a $\mathrm{DBH} \geq 20 \mathrm{~cm}$ were tagged, identified and measured. They were subsequently re-measured three (1995), seven (1999), thirteen (2005), seventeen (2009) and twenty (2012) years after logging.

\section{Aboveground biomass}

Stem diameter measurements were used to estimate the aboveground biomass (AGB) value for each measured tree using a general allometric equation (Equation 1) developed for tropical forests (Chave et al., 2005).

Tree species wood density was obtained in the Global Wood Density Database (GWDD) (Zanne et al., 2009). When only the genus was present or the species were not present in GWDD we used the same procedure adopted by Rutishauser et al. (2015), where WD was assigned as genus average or plot-average respectively.

$$
\begin{aligned}
& \mathrm{AGB}=(\rho \mathrm{X} \exp (-1.499+2.148 \ln (\mathrm{D})+0.207(\ln \\
& \left.\left.(\mathrm{D}))^{2}-0.0281(\ln (\mathrm{D}))^{3}\right)\right) / 1000
\end{aligned}
$$

Where: $\rho=$ wood specific gravity $\left(\mathrm{g} \mathrm{cm}^{-3}\right) ; \mathrm{AGB}=$ aboveground oven-dried biomass $\left(\mathrm{Mg} \mathrm{ha}^{-1}\right) ; \mathrm{D}=$ diameter at $1.30 \mathrm{~m}$ above ground level $(\mathrm{cm})$.

AGB before logging (AGBBL) was estimated based on a previous forest census carried out in 1991 (Oliveira \& Braz, 1998) and a logging operations damage constant obtained in the study area (Oliveira \& Braz, 1995). AGB was estimated as expressed by equation 2 .

$$
\mathrm{AGBBL}=\mathrm{AGBAL}+\mathrm{LAGB}+(\mathrm{LAGB} * 0.27)
$$

Where: $\mathrm{AGBBL}=$ aboveground biomass before logging; $\mathrm{AGBAL}=$ AGB one year after logging; LAGB = logged AGB; $0.27=$ logging damage constant.

Aboveground biomass was estimated as the sum of the biomass of living, dead and recruited trees in each measurement year. The biomass of dead trees was considered biomass loss and was computed as a negative number. The periodic annual ingrowth (PAI) and mortality (PAM) were calculated as the sum of the aboveground biomass of the recruits (trees that reached the minimum sampling DBH) and dead trees calculated in a census divided by the census interval (equations 3 and 4 , respectively). The periodic annual growth (PAG) of the living trees (growth of the trees present in a census and still alive in the next) was calculated as expressed by equation 5 .

$$
\begin{aligned}
& \text { PAI }=A G B \_\operatorname{Ing}_{t 1} / t \\
& \text { PAM }=\text { AGB_Mort }{ }_{t 1} \\
& \mathrm{PAG}=\left(\mathrm{AGB} \_\mathrm{St} t_{\mathrm{t} 1}-\mathrm{AGB} \_\mathrm{Ing}_{\mathrm{t}}\right)-\left(\mathrm{AGB} \_\mathrm{St} \mathrm{t}_{\mathrm{t} 0}-\mathrm{AGB}\right. \\
& \text { Mort } \left._{\mathrm{t} 1}\right) / \mathrm{t}
\end{aligned}
$$

Where: AGB_ST $\mathrm{t}_{\mathrm{t}}=$ above-ground biomass of the standing trees in a census; $A G B$ Ing ${ }_{t 1}=$ above-ground biomass of the ingrowth during the census interval; $\mathrm{AGB} \mathrm{ST}_{\mathrm{t} 0}=$ above-ground biomass of the standing trees in the previous census; AGB_Mort ${ }_{t 1}=$ above-ground biomass of the trees that died during the census interval; $\mathrm{t}=$ time in years between census.

\section{Statistical analyses}

We used repeated measures data analysis to compare the response trends over time regarding aboveground biomass to compare periods (time interval between one census and the next, e.g. 1992-1995) within treatments (logging). It was based on a general mixed model as expressed by equation 6 . The repeated measures model was determined by equation 7 .

$$
\mathrm{Y}=\mathrm{X} \beta+\mathrm{ZU}+\mathrm{e}
$$

Where: $X=$ matrix for fixed effects; $\beta=$ vector of the fixed effects of unknown parameters; $Z$ = matrix for random effects; $U=$ vector of unobservable random effects; $\mathrm{e}=$ vector of residual random errors.

$$
\mathrm{y}_{\mathrm{ijk}}=\mu+\alpha_{\mathrm{i}}+\tau_{\mathrm{k}}+\left(\alpha^{*} \tau\right)_{\mathrm{ik}}+\mathrm{e}_{\mathrm{ijk}}
$$

Where: $\mathrm{y}_{\mathrm{ijk}}=$ aboveground biomass of tree $\mathrm{j}$ at time $\mathrm{k}$ in plot I; $\mu=$ overall mean; $\alpha_{i}=$ fixed effect of management; $\tau_{k}=$ fixed effect of year or period $\mathrm{k} ;\left(\alpha^{*} \tau\right)_{\mathrm{ik}}=$ fixed interaction effect for plot $\mathrm{i}$ at time $\mathrm{k}$ or plot $\mathrm{i}$ at period $\mathrm{k} ; \mathrm{e}_{\mathrm{ijk}}=$ random error at time $\mathrm{k}$ in plot $\mathrm{i}$ or at period $\mathrm{k}$ in plot $\mathrm{i}$.

To process the data, we used the MIXED procedure (SAS 9.2) with repeated measures. The KR (KenwardRoger) option was employed to calculate degrees of freedom and compound symmetry for the covariance structure. When the overall $F$ test was significant $(p<$ 0.05 ), we used post-hoc least squares means (LS-means) tests with adjusted Tukey to determine significant differences $(p<0.05)$ between management (logged and unlogged) and periods. 


\section{Results}

\section{Rainfall}

The annual mean rainfall was $1,980 \pm 120 \mathrm{~mm}$ and varied from around $1,600 \mathrm{~mm}$ to $2,700 \mathrm{~mm}$ over the studied period. Only three years presented rainfall below the calculated $(p<0.05)$ confidence $(C I): 1995,2000$ and 2011. The dry season (May to August) accumulated

mean rainfall was $224 \pm 92 \mathrm{~mm}$, presenting a high variation between years with extremes of $80 \mathrm{~mm}$ (2005) and $470 \mathrm{~mm}$ (2012) mm. In 1998 and 2005 accumulated rainfall along dry season was below the CI $(\mathrm{p}<0.05)$. Months with accumulated rainfall below $100 \mathrm{~mm}$ varied from 3 to 6 over the study period. Long dry seasons ( 5 months or more) and below average accumulated rainfall between May and August occurred in 1998, 2005 and 2011 (Figure 1).

A
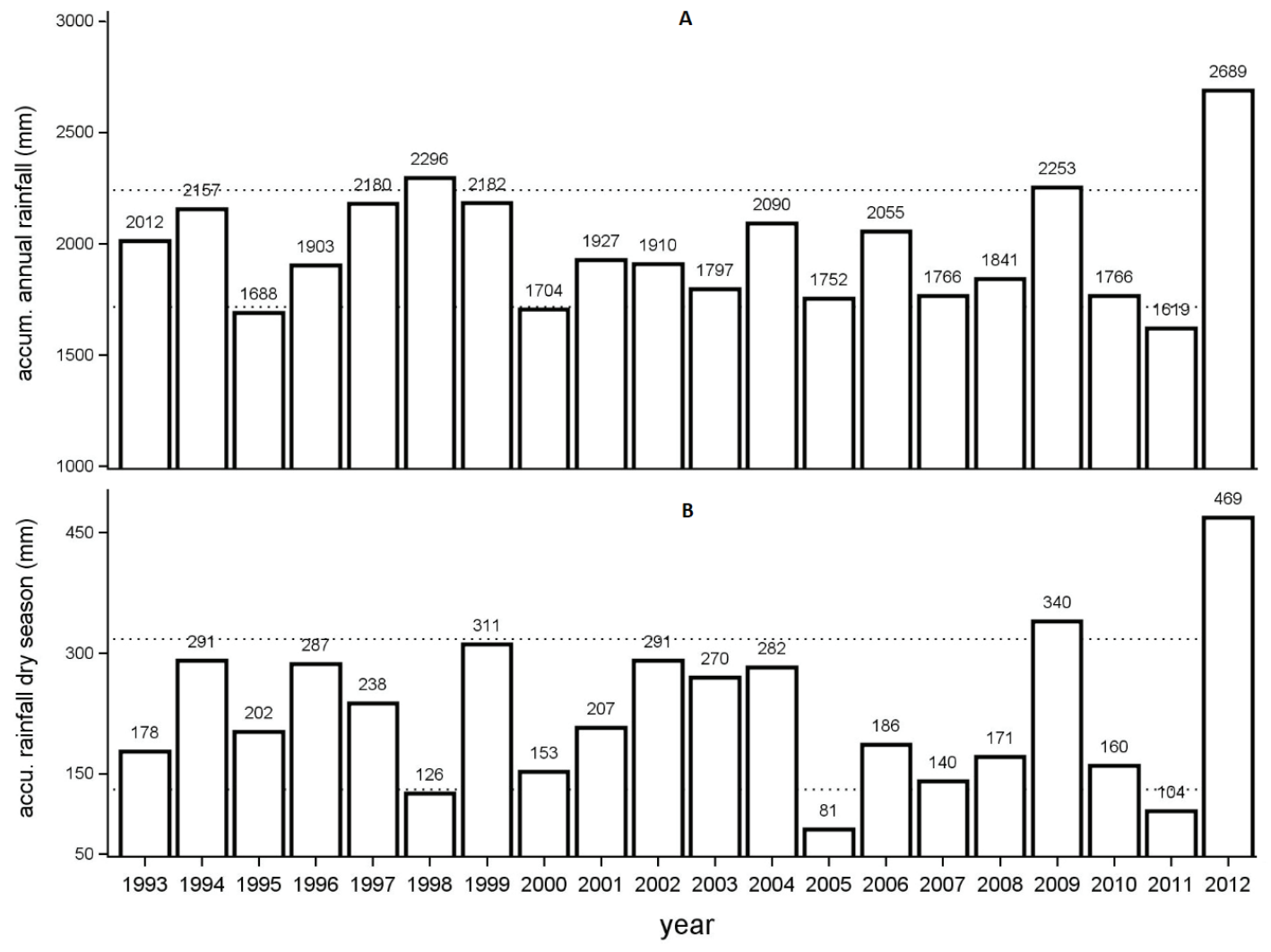

Figure 1. (A) Annual rainfall ( $\mathrm{mm}$ ) and (B) dry season (May - August) accumulated rainfall (mm) observed in Rio Branco, Acre Station (INMET - 82915). Horizontal gray lines represent the rainfall confidence interval $(\mathrm{p}<0.05)$ to $1992-2012$ period.

\section{Aboveground biomass}

Immediately after logging (1992) the mean standing trees (diameter at $1.3 \mathrm{~m}$ above ground level $-\mathrm{DBH} \geq$ $20 \mathrm{~cm}$ ) abovegrund biomass (AGB), for all permanent sample plots (PSP), was $205.2 \pm 26.9 \mathrm{Mg}$. ha ${ }^{-1}$, it showed an increasing, in the first measurement period (219.2 $\mathrm{Mg} \mathrm{ha}^{-1}$ ) that sharply decreased to 183.0 $\mathrm{Mg} \mathrm{ha}^{-1}$ between 1995 and 1999. At the end of the study period, mean AGB in the PSP $(221.4 \pm 12.3 \mathrm{Mg}$ $\mathrm{ha}^{-1}$ ) was similar to the estimated AGB before logging (228.3.4 $\pm 22.2 \mathrm{Mg} \mathrm{ha}^{-1}$ ) (Figure 2a). A similar AGB fluctuation was observed in the undisturbed (Figure $2 b$ ) and logged (Figure 2c) forests. Although over the study period mean AGB became higher in the logged areas (Figures $2 \mathrm{~b}$ and $2 \mathrm{c}$ ), no significant differences were found for period or management (Table 1). 


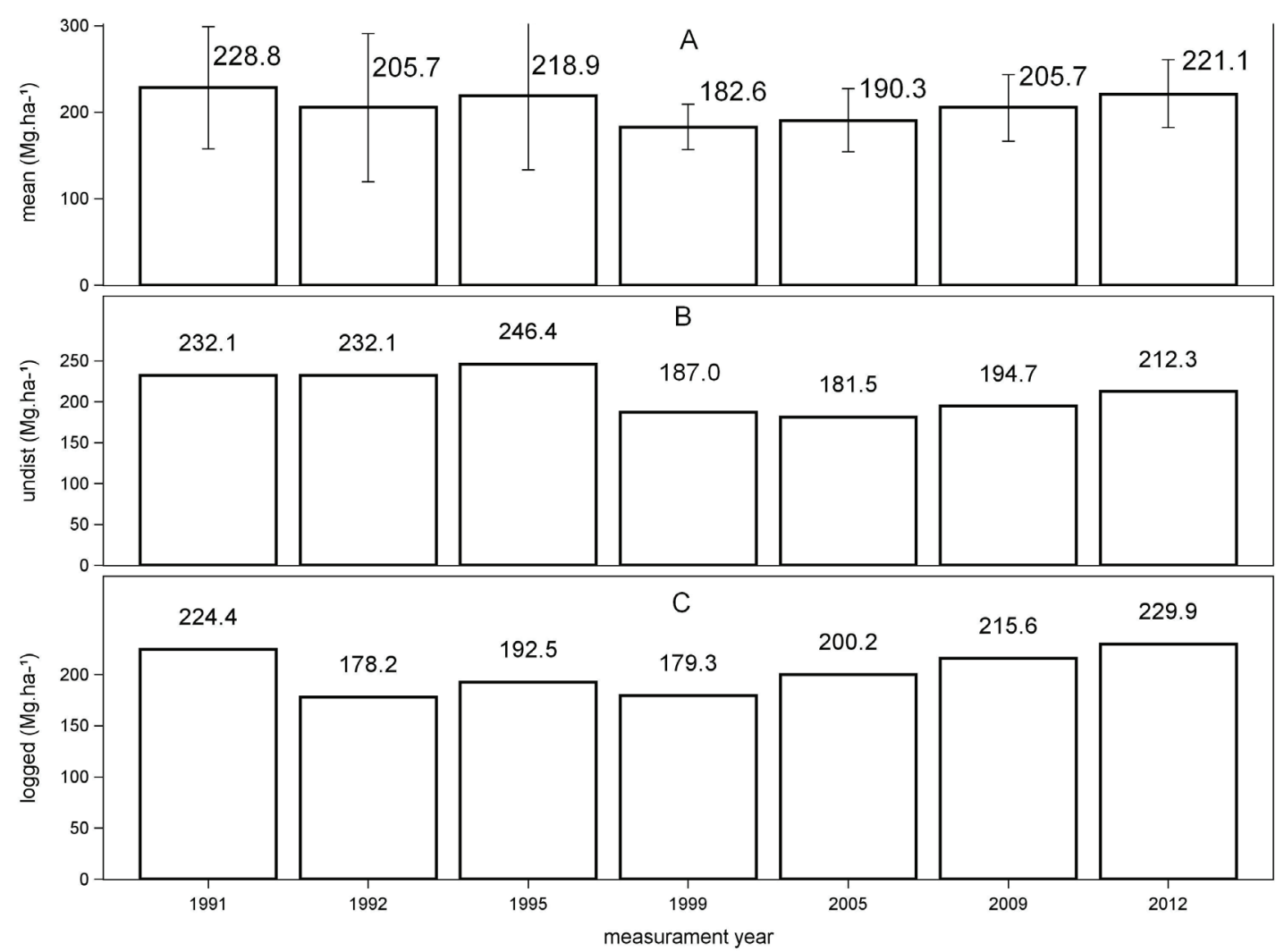

Figure 2. Standing trees' (diameter at $1.3 \mathrm{~m}$ above ground level $\geq 20 \mathrm{~cm}$ ) aboveground dried biomass $\left(\mathrm{AGB}-\mathrm{Mg} \mathrm{ha}^{-1}\right)$ increment for: A - all permanent sample plots (PSP) $(\mathrm{N}=4) ; \mathrm{B}$ - the undisturbed (undist) and C - logged PSP in the Embrapa Acre forest. Error bars represent the standard error $(p<0.05)$.

Standing trees' AGB growth rates were significantly higher in the logged areas $(\mathrm{t}=12.72, \mathrm{p}<0.01$ - Table 1 ; least-square means $p<0.01-$ Table 2). Independent of managed or unlogged areas, standing tree AGB growth was about constant in the first three measurement periods and linearly increased from 1999 to 2012.

Although AGB accumulated by ingrowth presented a peak after logging and decreased over the studied period it did not vary significantly (Figure 3).

AGB loss produced by logging was estimated as 46.2 $\mathrm{Mg} \mathrm{ha}^{-1}$. AGB loss was significantly higher in the second measurement period $(\mathrm{t}=7.11, \mathrm{p}<0.01-$ Table
1; contrasts presented in Table 2), producing mean AGB loss of $14.5 \mathrm{Mg} \mathrm{ha}^{-1} \mathrm{yr}^{-1}$ or a total of $59.0 \mathrm{Mg} \mathrm{ha}^{-1} \pm$ $18.8 \mathrm{Mg} \mathrm{ha}^{-1}$ from 1995 to 1999 (Figure 3).

The AGB accumulation balance (the AGB of the standing trees plus ingrowth less mortality) varied over the studied period from $-8.8 \mathrm{Mg} \mathrm{ha}^{-1} \mathrm{yr}^{-1}$ (1995-1999) to $5.6 \mathrm{Mg} \mathrm{ha}^{-1} \mathrm{yr}^{-1}$ (2009-2012). AGB accumulation balance was positive after logging $\left(4.5 \mathrm{ha}^{-1} \mathrm{yr}^{-1}\right)$ and negative $\left(-8.8 \pm 5.0 \mathrm{Mg} \mathrm{ha}^{-1} \mathrm{yr}^{-1}\right)$ in the next measurement period (1995-1999). This was the only period that presented a negative value for AGB balance over the study time (Figure 3). 
Table 1. Summary of type three tests of fixed effects of measurement year (year), between census interval (period) and management (man) for mixed model with repeated measures evaluating variation in aboveground biomass (AGB), ingrowth, growth and mortality in the Embrapa Acre forest permanent sample plots.

\begin{tabular}{|c|c|c|c|c|}
\hline Variables & Effect & DF & $\begin{array}{l}\text { F-test } \\
\text { value }\end{array}$ & $\operatorname{Pr}>\mathbf{F}$ \\
\hline \multirow{3}{*}{$\begin{array}{l}\mathrm{AGB}-\mathrm{Mg} \mathrm{ha}^{-1} \\
\quad \text { (Figure 3a) }\end{array}$} & year & 5 & 0.69 & 0.660 \\
\hline & man & 1 & 0.39 & 0.542 \\
\hline & year*man & 5 & 0.66 & 0.681 \\
\hline \multirow{3}{*}{$\begin{array}{c}\text { Ingrowth }-\mathrm{Mg} \mathrm{ha}^{-1} \mathrm{yr}^{-1} \\
\text { (Figure } 3 \mathrm{a})\end{array}$} & period & 4 & 0.39 & 0.809 \\
\hline & man & 1 & 4.67 & 0.057 \\
\hline & period*man & 4 & 0.66 & 0.637 \\
\hline \multirow{3}{*}{$\begin{array}{c}\text { Growth }-\mathrm{Mg} \mathrm{ha}^{-1} \mathrm{yr}^{-1} \\
(\text { Figure } 3 \mathrm{~b})\end{array}$} & period & 4 & 2.53 & 0.114 \\
\hline & man & 1 & 12.72 & $<0.01$ \\
\hline & period*man & 4 & 2.75 & 0.096 \\
\hline \multirow{3}{*}{$\begin{array}{c}\text { Mortality }-\mathrm{Mg} \mathrm{ha}^{-1} \mathrm{yr}^{-1} \\
\text { (Figure } 3 \mathrm{~b})\end{array}$} & period & 4 & 7.11 & $<0.01$ \\
\hline & man & 1 & 0.71 & 0.421 \\
\hline & period*man & 4 & 1.18 & 0.382 \\
\hline
\end{tabular}

$\mathrm{DF}=$ degrees of freedom; $\operatorname{Pr}>\mathrm{F}=$ probability associated with $F$-test.

Figure 3. Mean annual aboveground biomass (AGB) increment $\left(\mathrm{Mg} \mathrm{ha}^{-1}\right)$ produced by the standing trees ( $\mathrm{DAP} \geq 20 \mathrm{~cm}$ ) growth (white column), ingrowth (light gray column) and mortality (dark gray column) for: A - all PSP; $\mathrm{B}$ - for the logged and C for the undisturbed (undist) permanent sample plots (PSP) in the Embrapa Acre forest. Error bars represent the standard error $(\mathrm{p}<0.05)$.

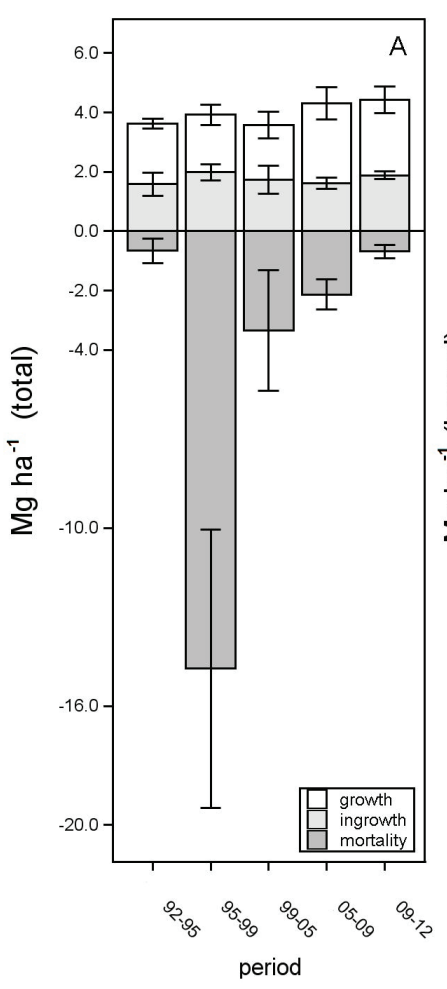

Table 2. Least-squares means (LSMEANS) pairwise comparison for the fixed effects management (logged and unlogged) and between census interval (period) on growth and mortality over the study period in the Embrapa Acre permanent sample plots.

\begin{tabular}{|c|c|c|c|}
\hline \multirow[t]{2}{*}{ Variable } & \multicolumn{2}{|c|}{ Fixed effect } & Adjusted \\
\hline & \multicolumn{2}{|c|}{ Management } & \\
\hline & logged & unlogged & \\
\hline \multirow[t]{2}{*}{$\begin{array}{c}\text { Growth } \\
\left(\mathrm{Mg} \mathrm{ha-}^{-1} \mathrm{yr}^{-1}\right)\end{array}$} & $3.2 \pm 1.2$ & $5.4 \pm 2.9$ & $<0.01$ \\
\hline & \multicolumn{2}{|c|}{ Period } & \\
\hline \multirow[t]{8}{*}{$\begin{array}{c}\text { Mortality } \\
\left(\mathrm{Mg} \mathrm{ha}^{-1} \mathrm{yr}^{-1}\right)\end{array}$} & P1992-1995 & p1995-1999 & \\
\hline & $0.6 \pm 0.4$ & $14.7 \pm 4.7$ & $<0.05$ \\
\hline & p1999-2005 & p1995-1999 & \\
\hline & $3.4 \pm 2.0$ & $14.7 \pm 4.7$ & $<0.05$ \\
\hline & p2005-2009 & p1995-1999 & \\
\hline & $2.1 \pm 0.5$ & $14.7 \pm 4.7$ & $<0.05$ \\
\hline & p2009-2012 & p1995-1999 & \\
\hline & $0.7 \pm 0.2$ & $14.7 \pm 4.7$ & $<0.05$ \\
\hline
\end{tabular}

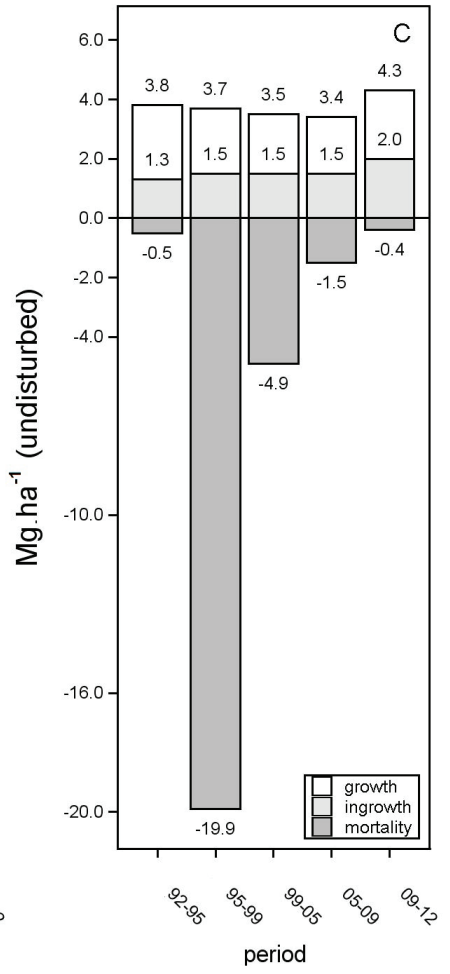

Pesq. flor. bras., Colombo, v. 37, n. 92, p. 493-502, out./dez. 2017 


\section{Discussion}

The long dry seasons (five to six months with accumulated rainfall below $100 \mathrm{~mm}$ ) observed during this study period coincided with the recorded ENSO events in other tropical forests around the world. The extreme climate events of 1997-1998 produced a high impact on the permanent sample plots (PSP) dynamic parameters, leveling managed and unlogged areas and eliminating the initial differences produced by logging. In the first measurement period alone, high biomass loss can be attributed to logging impacts. In the following measurements, it was associated with natural causes, which equally affected logged and unlogged areas, and the aboveground biomass (AGB) loss observed in the 1995-1999 period was greater than that estimated for logging.

We recognize that the absence of the PSP pre-logging measurement is a weakness of this work. However, the logged trees' diameters and damage constant we used to estimate the pre-logging AGB were based on a study (Oliveira \& Braz, 1995) carried out in the same area and year the PSP were established. This study included a prelogging forest census performed in 1991, where all trees with $\mathrm{DBH} \geq 50 \mathrm{~cm}$ were measured and identified, and the damage produced by forest operations (felled trees gaps, skid trails, road and landing) was assessed. The damage assessment considered all knocked down and broken trees with $\mathrm{DBH} \geq 10 \mathrm{~cm}$. The damage constant was obtained through the assessment of $70 \%$ (57 out of 85 ) of all logged trees in the 20 ha area, which makes this constant sufficiently reliable.

The AGB loss and tree mortality observed in this study was also widely reported by other studies on tropical forests (Nakagawa et al., 2000, in Malaysia; Williamson et al., 2000, in Brazilian Central Amazon; Condit et al., 2004, in Panama; Slik, 2004, in Indonesia; Rolim et al., 2005, in the Atlantic Rain Forest, Brazil; Clark et al., 2003, in Central America) as being caused by a severe drought associated with the 1997-1998 El Niño. These results, allied with the presented rainfall data, indicate that our assumption that the AGB loss observed in the 1995-1999 period was caused by an ENSO event was consistent.

Considering the entire study period, the mean AGB accumulation balance in all plots was close to null, a result similar to the one obtained by Rolim et al. (2005) in an 22 year study in an undisturbed Atlantic forest where the biomass gain was cancelled out by biomass loss associated with El Niño events (1987 and 1998). In their study, the 1998 ENSO event had less impact on forest biomass, because most drought-susceptible large trees died during the 1987 event. It is important to emphasize that in our study this result included the recovery of the AGB loss produced by logging in the managed plots, promoted by a significantly higher tree growth and (although not statistically significant, $\mathrm{p}=$ 0.057) higher ingrowth.

The linear AGB accumulation observed from 1999 to the end of the study was produced by the combination of the standing trees' growth increase and trees' mortality decrease. The growth increase in the living standing trees that remained was expected as a consequence of the reduction in the competition for light and soil moisture due to the death of neighboring individuals (e.g. Brando et al., 2008) and the canopy opening produced by the large trees' mortality (associated with logging and climate), which also favored ingrowth. The relatively slow reduction in tree mortality rates, e.g. different from Williamson et al. (2000), where it sharply dropped after the El Niño, can be attributed to the subsequent droughts of 2005 and 2011 (e.g. also observed in the same region by Oliveira et al., 2013), reflected in the low AGB accumulation balance of both periods. In the last measurement twenty years after logging, ingrowth and mortality rates were similar to what would be expected in an undisturbed forest, and the high standing trees' increment rates indicate that the AGB accumulation will probably remain high in the next years.

\section{Final considerations}

The main concern about tropical forest management is whether a forest will or will not recover from logging impacts over the duration of the cycle. Most of the recent studies point out that aboveground biomass (AGB) usually presents a fast recovery (Sist \& Ferreira 2007; Peña-Claros et al., 2008; Macpherson et al., 2010; Rutishauser et al., 2015). This study confirms these results, but in our study, natural causes produced stronger effects on the forest dynamics than did the initial logging impact. We also found significant advantages for AGB accumulation and ingrowth in the logged areas.

Our results are also consistent with the general view that: i. forested ecosystems are already responding to climate changes (Allen et al., 2010 and Feeley et al., 
2011); ii. Long-term climate events will produce strong changes in the forest dynamics, structure and species composition, probably severely reducing forest biomass (e.g. Phillips et al., 2009; Negrón-Juarez et al., 2010), and iii. if the frequency and intensity of these events increase, a persistent alteration in the forest canopy (Saatchi et al., 2012) and a decline in the rates of the net aboveground biomass increase should be expected (Brienen et al., 2015).

Besides deforestation, logging has been recognized as a main source of tropical forest degradation (Zimmerman \& Kornos, 2012). Considering the climate change scenario, it is reasonable to extend these concerns also to the impacts produced by natural causes in undisturbed forests. However, although climate has already been recognized as an important factor in the tropical forest structure, species composition and dynamics, driving these forests to a non-equilibrium state, no practical adaptation management or conservation measures have been suggested to increase their resilience to ENSO events. Even recognizing the limitations in the scale of this study, the results indicate that both managed and unmanaged forests will be exposed to changes in structure over time, and the ideal view of a forest management prescription, which predicts a return to the exact pre-disturbance original state, is unrealistic. Also, the controlled removal of commercial-size trees (e.g. above a minimum cutting diameter of $50 \mathrm{~cm}$ $\mathrm{DBH})$, promoting controlled disturbances in the forest through the appliance of reduced impact logging (RIL) techniques during forest operations, should be a way to prevent the biomass loss produced by the observed higher mortality of big trees (Phillips, et al., 2010) during ENSO events.

\section{References}

Allen, C. D. et al. A global overview of drought and heat-induced tree mortality reveals emerging climate change risks for forests. Forest Ecology and Management, v. 259, n. 4, p. 660-684, 2010. DOI: 10.1016/j.foreco.2009.09.001.

Baker, T. R. et al. Increasing biomass in Amazonian forest plots. Philosophical Transactions of the Royal Society B, v. 359, n. 1.443, p. 353-365, 2004. DOI: 10.1098/rstb.2003.1422.

Blanc, L. et al. Dynamics of aboveground carbon stocks in a selectively logged tropical forest. Ecological Applications, v. 19, n. 6, p. 1397-1404, 2009. DOI: 10.1890/08-1572.1.

Pesq. flor. bras., Colombo, v. 37, n. 92, p. 493-502, out./dez. 2017
Brando, P. M. et al. Drought effects on literfall, wood production and belowground carbon cycling in Amazon forest: results of a throughfall reduction experiment. Philosophical Transactions of the Royal Society B, v. 363, n. 1.498, p. 1839-1848, 2008. DOI: 10.1098/rstb.2007.0031.

Bicknell, J. E. et al. Reconciling timber extraction with biodiversity conservation in tropical forests using reduced-impact logging. Journal Applied Ecology, v. 52, n. 2, p. 379-388, 2015. DOI: 10.1111/1365-2664.12391.

Boisvenue, C. \& Running, S. W. Impacts of climate change on natural forest productivity - evidence since the middle of the 20th century. Global Change Biology, v. 12, p. 862-882, 2006. DOI: 10.1111/j.1365-2486.2006.01134.x.

Boletim Agrometeorológico. Rio Branco, AC: EMBRAPA-CPAF, 1990. (EMBRAPA-CPAF. Boletim Agrometeorológico, 5).

Boletim Agrometeorológico. Rio Branco, AC: EMBRAPA-CPAF, 1995. (EMBRAPA-CPAF. Boletim Agrometeorológico, 6).

Brienen, R. J. W. et al. Longterm decline of the Amazon carbon sink. Nature, v. 519, p. 344-348, 2015. DOI: 10.1038/nature14283.

Brown, F. et al. Brazil: drought and fire response in the Amazon. World resources report, Washington, DC, 2011. Available from: $<$ http://www.worldresourcesreport.org $>$. Access on: 10 jan. 2017.

Chave, J. et al. Tree allometry and improved estimation of carbon stocks and balance in tropical forests. Oecologia, v. 145, p. 87-99, 2005. DOI: $10.1007 / \mathrm{s} 00442-005-0100-x$.

Clark, D. A. et al. Tropical rain forest tree growth and atmospheric carbon dynamics linked to interannual temperature variation during 1984-2000. Proceedings of the National Academy of Sciences, v. 100, n. 10, p. 5852-5857, 2003. DOI: 10.1073/pnas.0935903100.

Condit, R. et al. Tropical forest dynamics across a rainfall gradient and the impact of an El Niño dry season. Journal of Tropical Ecology, v. 20, p. 51-72, 2004. DOI: 1017/S0266467403001081.

Dauber, E. et al. Sustainability of timber harvesting in Bolivian tropical forests. Forest Ecology and Management, v. 214, p. 294-304, 2005. DOI: 10.1016/j.foreco.2005.04.01910.1016/j. foreco.2005.04.019.

Edwards, D. P. et al. Maintaining ecosystem function and services in logged tropical forests. Trends in Ecology and Evolution, v. 29, p. 511-520, 2014. DOI: 10.1016/j.tree.2014.07.003.

Feeley, K. J. et al. Directional changes in the species composition of a tropical forest. Ecology, v. 92, p. 871-882, 2011. DOI: 10.1890/100724.1 .

Fredericksen, T. S. \& Mostacedo, B. Regeneration of timber species following selection logging in a Bolivian tropical dry forest. Forest Ecology and Management, v. 131, p. 47-55, 2000. DOI: 10.1016/ S0378-1127(99)00199-110.1016/S0378-1127(99)00199-1.

Fredericksen, T. S. \& Putz, F. E. Silvicultural intensification for tropical conservation. Biodiversity \& Conservation, v. 12, p. $1445-$ 1453, 2003. DOI: 10.1023/A:1023673625940.

Gourlet-Fleury, S. et al. Tropical forest recovery from logging: a 24 year silvicultural experiment from Central Africa. Philosophical Transactions of the Royal Society of London B, v. 368, p. 1-10, 2013. DOI: $10.1098 /$ rstb.2012.0302. 
Instituto Nacional de Meteorologia. Banco de dados meteorológicos para ensino e pesquisa. 2014. Available from: $<$ http://www.inmet. gov.br/portal/index.php?r=bdmep/bdmep $>$. Access on: .

Laurance, S. G. W. et al. Long-term variation in Amazon forest dynamics. Journal of Vegetation Science, v. 20, n. 2, p. 323-333, 2009. DOI: $10.1111 /$ j.1654-1103.2009.01044.x.

Lewis, S. L. et al. Concerted changes in tropical forest structure and dynamics: evidence from 50 South American long-term plots. Philosophical Transactions of the Royal Society of London B, v. 359, p. 421-436, 2004. DOI: 10.1098/rstb.2003.1431.

Macpherson, A. J. et al. A model for comparing reduced impact logging with conventional logging for an Eastern Amazonian Forest. Forest Ecology and Management, v. 260, p. 2002-2011, 2010. DOI: 10.1016/j.foreco.2010.08.0500.1016/j.foreco.2010.08.050.

Malhi, Y. et al. An international network to monitor the structure, composition and dynamics of Amazonian forests (RAINFOR). Journal of Vegetation Science, v. 13, p. 439-450, 2002. DOI: 10.1111/j.1654-1103.2002.tb02068.x.

Miller, S. D. et al. Reduced impact logging minimally alters tropical rainforest carbon and energy exchange. Proceedings of the National Academy of Sciences, v. 108, n. 48, p. 19431-19435, 2011. DOI: 10.1073/pnas.1105068108.

Nakagawa, M. et al. Impact of severe drought associated with the 1997-1998 El Niño in a tropical forest in Sarawak. Journal of Tropical Ecology, v. 16, n. 3, p. 355-367, 2000.

Nebel, G. et al. Forest dynamics in flood plain forests in the Peruvian Amazon: effects of disturbance and implications for management. Forest Ecology and Management, v. 150, p. 79-92, 2001. DOI: 10.1016/S0378-1127(00)00682-4.

Negrón-Juárez, R. I. et al. Widespread amazon forest tree mortality from a single-basin squall line event. Geophysical Research Letters, v. 37, 2010. DOI: 10.1029/2010GL043733.

Nemani, R. R. et al. Climate-driven increases in global terrestrial net primary production from 1982 to 1999 . Science, v. 300, p. 1560-1563, 2003. DOI: $10.1126 /$ science. 1082750 .

Nepstad, D. C. et al. Amazon drought and its implications for forest flammability and tree growth: a basin-wide analysis. Global Change Biology, v. 10, p. 704-717, 2004. DOI: 10.1111/j.15298817.2003.00772.x.

Nepstad, D. C. et al. Mortality of large trees and lianas following experimental drought in an amazon forest. Ecology, v. 88, p. 2259-2269, 2007. DOI: 10.1890/06-1046.1.

Oliveira, M. V. N. d'\& Braz, E. M. Manejo florestal em regime de rendimento sustentado, aplicado à floresta do Campo Experimental da Embrapa CPAF-AC. Rio Branco, AC: Embrapa CPAF-AC, 1998. 45 p. (Embrapa CPAF-AC. Boletim de pesquisa, 21).

Oliveira, M. V. N. d' \& Braz, E. M. Reduction of damage to tropical moist forest through planned arvesting. The Commonwealth Forestry Review, v. 74, n. 3, p. 208-210, 1995.

Oliveira, M. V. N. d' et al. Can forest management be sustainable in a bamboo forest? A 12-year case study of forest dynamics in western Amazon. Forest Ecology and Management, v. 310, p. 672-679, 2013. DOI: 10.1016/j.foreco.2013.09.008.
Pan, Y. et al. A large and persistent carbon sink in the world's forests. Science, v. 333, p. 988-993, 2011. DOI: 10.1126/science.1201609.

Peña-Claros, M. et al. Beyond reduced-impact logging: silvicultural treatments to increase growth rates of tropical trees. Forest Ecology and Management, v. 256, p. 1458-1467, 2008. DOI: 10.1016/j. foreco.2007.11.01310.1016/j.foreco.2007.11.013.

Phillips, O. L. et al. Drought sensitivity of the Amazon Rainforest. Science, v. 323, p. 1344-1347, 2009. DOI: 10.1126/science.1164033.

Phillips, O. L. et al. Drought-mortality relationships for tropical forests. New Phytologist, v. 187, p. 631-646, 2010. DOI: 10.1111/j.1469-8137.2010.03359.x.

Putz, F. E. \& Redford, K. H. The importance of defining 'forest': tropical forest degradation, deforestation, long-term phase shifts, and further transitions. Biotropica, v. 42, p. 10-20, 2010. DOI: 10.1111/j.1744-7429.2009.00567.x.

Rolim, S. G. et al. Biomass change in an Atlantic tropical moist forest: the ENSO effect in permanent sample plots over a 22-year period. Oecologia, v. 142, p. 238-246, 2005. DOI: 10.1007/s00442004-1717-x.

Rutishauser, E. et al. Rapid tree carbon recovery in managed Amazonian forests. Current Biology, v. 25, p. 787-788, 2015. DOI: 10.1016/j.cub.2015.07.034.

Saatchi, S. et al. Persistent effects of a severe drought on Amazonian forest canopy. Proceedings of the National Academy of Sciences, v. 110, p. 565-570, 2012. DOI: 10.1073/pnas.1204651110.

Sheil, D. A half-century of permanent plot observation in Budongo forest Uganda: histories, highlights, and hypotheses. In: Dallmeier, F. \& Comiskey, J.A. (Ed.). Forest biodiversity research, monitoring and modeling: conceptual background and old world case studies. Paris: Unesco: The Pathernon Publishing Group, 1998. p. 399-428. (Man and the biosphere series, v. 20).

Sist, P. et al. The Tropical managed Forests Observatory: a research network addressing the future of tropical logged forests. Applied Vegetation Science, v. 18, p. 171-174, 2015. DOI: 10.1111/ avsc. 12125 .

Sist, P. \& Ferreira, F. N. Sustainability of reduced-impact logging in the Easter Amazon. Forest Ecology and Management, v. 243, p. 199-209, 2007. DOI: 10.1016/j.foreco.2007.02.01410.1016/j. foreco.2007.02.014.

Slik, J.W. El Niño droughts and their effects on tree species composition and diversity in tropical rain forests. Oecologia, v. 141, p. 114-120, 2004. DOI: 10.1007/s00442-004-1635-y.

Toledo, M. et al. Climate is a stronger driver of tree and forest growth rates than soil and disturbance. Journal of Ecology, v. 99, p. 254264, 2011. DOI: 10.1111/j.1365-2745.2010.01741.x.

Villegas, Z. et al. Silvicultural treatments enhance growth rate of future crop trees in a tropical dry forest. Forest Ecology and Management, v. 258, p. 971-977, 2008. DOI: 10.1016/j. foreco.2008.10.03110.1016/j.foreco.2008.10.031.

Wadsworth, H. F. \& Zweed, J. C. Liberation: acceptable production of tropical forest timber. Forest Ecology and Management, v. 233, p. 45-51, 2006. DOI: 10.1016/j.foreco.2006.05.072. 
West, T. A. P. et al. Forest biomass recovery after conventional and reduced-impact logging in Amazonian Brazil. Forest Ecology and Management, v. 314, p. 59-63, 2014. DOI: 10.1016/j. foreco.2013.11.02210.1016/j.foreco.2013.11.022.

Williamson, G. B. et al. Amazonian tree mortality during the 1997 El Niño drought. Conservation Biology, v. 14, p. 1538-1542, 2000. DOI: 10.1046/j.1523-1739.2000.99298.x.
Zanne, A. E. et al. Towards a worldwide wood economics spectrum. In: Dryad Digital Repository. 2009. Available from: < https://doi. org/10.5061/dryad.234>. Access on:

Zimmerman, B. L. \& Kornos, C. Prospects for sustainable logging in tropical forests. BioScience, v. 62, p. 479-487, 2012. DOI: 10.1525/ bio.2012.62.5.9. 